\title{
Tour Guides and Destination Image: Evidence From Portugal
}

\author{
Alexandra Matos Pereira \\ University of Coimbra, Coimbra, Portugal
}

\begin{abstract}
Tourist guides as front-line professionals, information-givers, and interpreters act as destination representatives and "ambassadors" in the eyes of tourists (Rabotić, 2010). This paper, using an empirical analysis of coach tour foreign tourists travelling in Portugal, intends to determine how tourist destination image (TDI) is modified and enhanced through the influence of tourist guide performance and tourist satisfaction with the guided tour. A survey questionnaire of first-time package tour travellers to Portugal revealed a positive change in attitude to image components such as monuments/museums, tourist information, landscape, and gastronomy and wines, confirming that the tourist guide's attributes in communication skills and scholar knowledge (history, art, and popular culture) together with highly rated tourist satisfaction with the guided tour concerning the professional competence of a bus driver were critical in enhancing Portugal destination image. Marketing implications for senior coach tour in Portugal are drawn.
\end{abstract}

Keywords: tourist guide, tourist guide performance, tourist satisfaction, coach guided tour, destination image

\section{Introduction}

Today, it is difficult to perceive organized tourism without the service of guides (Rabotić, 2010). Guiding has been related to a variety of issues through its connections with innovation, politics, economy, social interactions, culture, indigenous tourism, local versus global, or to sustainability, storytelling, education, commodification, performance, and authenticity (Zillinger, Jonasson, \& Adolfsson, 2012). This multiplicity of connections makes it difficult to define the guide approach.

A guide, latosensu, can be a tour manager or a tour escort when the itinerary is supervised on behalf of the tour operator and basic assistance is provided to travellers (this professional is named in Portuguese Correio de Turismo). But a guide can also be a tourist guide when groups are welcomed at a destination and visitors guided in the language of their origin, with interpretation of the cultural and natural heritage of the area. In Portugal, they are referred as Guias-Intérpretes (European Committee for Standardization, 2003). This study takes into account this last category.

Going through literature, Schmidt's (1979), Holloway's (1981), and Cohen's (1985) studies on guiding belong to the classics. The 1990s brought, among others, Hughes (1991) with a study on visitors' satisfaction with the guide and Pond (1993) on the importance and duties of guides. After the millennium, the themes that often occur are more of an intangible kind: perceptions, values, roles, culture, knowledge, education, narratives, memories, or performance (Zillinger et al., 2012).

Alexandra Matos Pereira, Ph.D., research student, Department of Geography, University of Coimbra. Email: alexandrammatospereira@gmail.com. 
Independently of their approach, what all researchers agree is "that guided tours are not simply mechanical procedures where groups of people are herded as urban cattle in search for a postmodern experience pasture". Rather, "guided tours are complex products that are improvised and created in situ" (Zillinger et al., 2012, p. 6).

This understanding shows us the emergence of an awareness of guiding as an important tool for the production of destination images (Zillinger et al., 2012). And to this respect, research exploring how tourist guide performance influences tourists' destination image is scarce (K. C. Chang, 2014).

Destination image has long been evaluated in literature. Several studies have centred on the relationship between destination image and preference or visitation intentions (Fakeye \& Crompton, 1991; Goodrich, 1978; Hunt, 1975; Milman \& Pizam, 1995; Scott, Schewl, \& Frederick, 1978). Others focused on the measurement of destination image (Echtner \& Ritchie, 1991; 1993), its components (Dann, 1996), or factors influencing it (Baloglu \& Brinberg, 1997). Still others examined temporal influences on image change (Gartner, 1986), differences between tourist image (demand) and what is projected by destinations (Stabler, 1990), and the relationship between socio-demographic variables and destination image (Baloglu, 1997; Baloglu \& McCleary, 1999).

For Zhang and Chow (2004), the success of the tourism industry very much depends on the performance of tourist guides in each destination. Tourist guides are the front-line staff who provide the "moment of truth" for tourists and can make or break their trip.

But understanding the influence of tourist guide performance on tourist's destination image cannot be determined without taking into account, at the same time, the tourist's satisfaction with the guided tour, as satisfaction interferes directly with the visiting experience. If a tourist is badly received by the professional who accompany him/her, even visiting the most beautiful place in the world, he/she will be left with a negative opinion that, keenly, will propagandize and will affect the image of the visited destination. Therefore, this study considers the tourist's satisfaction with the guided tour and tourist guide performance, two constructs that will exert a joint influence on Portugal destination image, acknowledged by tourists' changed opinion under the influence of the tourist guide.

The contribution of this study to the tourism literature is therefore three-fold. First, this study develops a conceptual model to explore the correlational relationships between tour guide performance and destination image. Second, this study collects data from foreign coach tourists traveling in Portugal to test hypothesized interrelationships in the model. Third, this study examines the relative effects of tour guide performance and satisfaction with guided tour on destination image; it also offers practical insights for tour guides, explaining how tourists weigh these factors differently. In short, the main purposes of this study are:

(1) To take the guided tours around Portugal as a case study to investigate the variables that influence destination image, excluding the basic demographics of the tourists;

(2) To suggest a conceptual framework for destination image through guided tours to assess the relationship of influencing variables as key factors in the satisfaction with the guided tour and the tourist guide performance quality;

(3) To present research results on the correlation between tourist guide performance and satisfaction with the guided tour, satisfaction with the guided tour and destination image, and finally, tourist guide performance and destination image;

(4) To provide suggestions for the enhancement of the tour guide performance and further explain the relationship of different influencing variables on the country destination image. 


\section{Theory Background}

\section{Tourist Guide Performance}

Adapting an internationally accepted definition given by the European Federation of Tourist Guide Associations, tourist guide is defined here as a person who guides groups around the buildings, sites, and landscapes of a city or a region, to interpret in an inspiring and entertaining manner the cultural and natural heritage and environment (Black \& Weiler, 2005).

Agreeing on the fact that guides are of vital importance for both tourism and tourist experience, several authors have dedicated their attention to the guide's role. For Rabotić (2010), the origin and evolution of the guide's role was expounded by Cohen (1985), a pioneer of making tourist guiding a matter of scientific attention. In his opinion, the role of professional guides consists of two components: social mediation and cultural brokerage. Cohen (1985) especially emphasized the significance of interpretation, identifying the term with intercultural mediation, explaining it as "translation" of foreign and unknown elements of the host culture into a cultural "idiom" which is close to the guest. Such "translation" is often necessary, since the majority of tourists spend only a short time at a destination, hardly possess any local knowledge, and view their temporary surrounding from a leisure perspective of tourist activity. Therefore, most of them cannot comprehend the local values, beliefs, tradition, and everyday life of inbound tourist regions (Rabotić, 2010).

The task of guides is to help visitors in locating, perceiving, and understanding the different features of a destination. No one else is in such a position in terms of tourists and possibilities of influence. This is the reason why Pond (1993) saw the guide as a medium which allows, enables, and encourages matters to develop: "In practice, it demands the greatest level of maturity and courage, for it requires that guides subordinate themselves to the traveller and the experience" (Rabotić, 2010, p. 3). It is part of the "ambassador's responsibility" (Yu, Weiler, \& Ham, 2002) of contemporary guides.

Therefore, in practice, tourist guide performance is based on the tourist guide's fulfilling several functions. Tourist guides manage tours and have great knowledge of a particular destination. They also interact with inbound tourists directly and hourly during the entire itinerary and provide tourists with safe, enjoyable, and rewarding experiences (K. C. Chang, 2014; Min, 2012). So, the interactions between tourists and tourist guides are very important and the communication competence of the tourist guide plays a significant role in the perceived success or failure of the tourism experience (Cohen, 1985; Leclerc \& Martin, 2004; Pearce, 1984).

Numerous researchers have presented outstanding methods for measuring tourist guide performance from tourists' perspectives by hypothesizing about their own dimensions of tourist guide performance (K. C. Chang, 2014). For example, Zhang and Chow (2004) proposed 20 service quality attributes to rate tourist guide performance in Hong Kong. Wang, Hsieh, Chou, and Lin (2007) employed multistage steps to validate a scale for measuring the group package tour service in Taiwan. In their study, six items for tour leader attributes (good presentation ability, a sense of responsibility, friendliness, interpretive ability, professional ability, and an ability to coordinate within group members) were extracted. Huang, Hsu, and Chan (2010), in a review of relevant literature of tourist guide performance attributes, summarized 35 items to evaluate the relationships between tourist guide performance and tourist satisfaction in Shanghai, China. The results showed that tourist guide service performance largely determines tourist satisfaction with the tourist guide services.

The results of the above-mentioned studies imply that the intangible service constructs are more important than tangible constructs for tourists to assess tourist guide service performance (K. C. Chang, 2014). Because service performance is a concept closely related to service quality (Huang et al., 2010), service 
quality, as perceived by the customer, is defined as "the extent of discrepancy between customers' expectations or desires and their perceptions" (Zeithaml, Parasuraman, \& Berry, 1990, p. 19). Therefore, customers are satisfied when their judgment of the service they have received (perception) equals or exceeds what they expected (K. C. Chang, 2014).

In the tourism context, if a tourist guide performs well during the itinerary, it is assumed that this performance would greatly improve the tourists' satisfaction with the journey. However, an unsatisfactory tourist guide may ruin the tourists' enjoyment of their holiday (Lopez, 1980). Therefore, in terms of customer satisfaction as proposed, if the performance of the tourist guide meets expectations or exceeds expectations during the journey, the tourists are satisfied or delighted, and when expectations are not met, they are dissatisfied (K. C. Chang, 2014; McDowall, 2010). That is, tourist guides performing quality services (e.g., providing information, interpreting the cultural and natural heritage, handling problems, and insulating tourists from difficulties, etc.) throughout the journey (Zhang \& Chow, 2004) are likely to gain tourists' trust, which can then strengthen their confidence and reduce risk perceptions when opinating about a destination or recalling the tourist experience.

\section{Destination Image}

There are two main schools of studies in terms of dimensions that make up the tourist destination image (TDI) construct.

The first one, which can be called school of components or basic dimensions, points to the existence of cognitive and affective elements whose interaction originates the third component forming the image, the conative (Baloglu \& McCleary, 1999; Gutiérrez, 2005). The cognitive dimension is the rational analysis of the measurable attributes of the destination, while the affective dimension refers to the visitor's feelings towards it. The inter-relationship of the cognitive component with the affective one results in the conative component. This conative component indicates the global tourist's behaviour in relation to the destination (Baloglu \& McCleary, 1999; Gutiérrez, 2005).

The second school (Echtner \& Ritchie, 1991; Gutiérrez, 2005) develops around a tridimensional model, with three continuous, each divided into two poles. The first continuous or image size goes from the "holistic" to "attributes". The second, termed vertical continuum, scrolls from "functional" to "psychological" characteristics and the third, diagonal continuous goes through the "common" to "unique". Critics to this scaling model image construct argue that it considers poorly the intangible or abstract aspects of the destination (Gil, Palacio, \& Santana, 2004).

Another perspective in the study of TDI is the model of the seven stages of travel experience developed by Gunn (1988) that relates changing in TDI according to the information available to the consumer, the kind of attractions offered by the destination and the visitor's experience at the destination (Neves, 2012). Once visited a tourist destination, tourists develop, based on actual experience, a more complete and realistic picture, that is to say, a full image (Almeida, Miranda, \& Elias-Almeida, 2012). Leaning on Gunn (1988), Fakeye and Crompton (1991) categorized the image of a destination in three stages, adding to the organic and induced the complex picture image. They proposed that destination images are formed at different stages: organic, induced, and experiential. The organic image is developed through an individual's everyday assimilation of information, from school geography readings to mass media. The induced image, on the other hand, is formed through the influence of tourism promotions by DMOs such as destination brochures, advertising, and travel editorials. Finally, the experiential component is based on the personal experience of visiting the destination. 
The multiplicity of TDI is visible in the methodological choice for measurement. Additionally, image is relative, based on a subjective assessment. However, there is no consensus on whether perceived image results from an individual evaluation (Crompton, 1979) or it is based on the collective impression of various individuals (Embacher \& Buttle, 1989; Hunt, 1975). Beerli and Martín (2004) provided an alternative explanation that includes both views; they determined that image evaluations do not change from one person to another, but rather vary according to individual segments in line with their socio-demographic characteristics. Under this perspective, Pereira and Cravidão (2014) demonstrated that the tourist gaze is not only based on the binary relation of Foucault's clinical gaze, but in a relational practice in which the collective gazers (Urry \& Larsen, 2011) of package tours converge to identical opinions on the destination, on an organized team gazing, even with initial different perceptions.

The formation of image, described as the development of a mental construct based upon impressions chosen from a flood of information (Echtner \& Ritchie, 1991) is, above all, the expression of all knowledge, impressions, and emotions that an individual or group has when visiting a particular place, especially if they are escorted by a tourist guide. Image will be affected and modified based upon first-hand information provided by the tourist guide and experience, as it will be demonstrated in the following section.

\section{Tourist's Satisfaction With Guided Tours}

"Many people's first thought of guided tours is that of a herd of people, following a woman with a yellow umbrella; this is not always a positively afflicted image of this phenomenon. Guided tours have been both stereotyped and ridiculed in everyday talk, being considered as a highly choreographed action" (Zillinger et al., 2012, p. 1). In addition to this, visitors taking part in guided tours have long been considered as being passive and rather naïve, walking pre-defined paths without questioning the content of the tour, or departing from the heteronymous route. These perceptions have contributed to a stereotyped image of guided tours, at times dismissed in both tourists' perceptions and academic writing (Zillinger et al., 2012).

As early as 1979, Schmidt stated that there are four functions of guided tours. Firstly, tourists do not have to choose themselves which sites to visit on occasions when time is limited. Secondly, travelling in a group with accordingly different positions, guided tours can act as a compromise for the individual group members. Thirdly, tourism can be legitimized by the educational contribution that a guided tour would bring, and lastly, it is a safe way to get to know a new place. Mediation has a central position in creating tourist experiences. Postmodern tourists and especially group travellers are not ready to invest greater intellectual and physical effort into their experience while travelling. As a result, the visited destination for them may remain a patchwork of fleeting images and signs appearing and disappearing in front of their very eyes. It is the guide who helps tourists to "move forward" by selecting and interpreting cultural peculiarities (otherwise ignored or misunderstood) since as a "symbol specialist", he or she offers explanations of "hardly available" signs (Rabotić, 2010, p. 4).

Touring tourist satisfaction can be measured according to different stakeholders involved in this type of tourism. Tour operators will be worried with the operational conditions of the tour and the guide's performance; the bus driver with the guide's compliance with schedules; the attractions responsible for the guide's leadership of the group, the group of tourists with the skills of the guide to deal with all the fronts at the same time, without failing. If the professional services of the guide do not meet the desirable standards, consequently all the members of the group will resent with that, and the tourist experience may be badly rated, corresponding to 
tourist dissatisfaction. On the other hand, if tourists are satisfied with everything they live during their visit, and satisfaction is a very immediately state of spirit, then a long queue of satisfactory episodes can make the tourist experience unforgettable.

In the study of Ham and Weiler (2007), the relationship between service-specific satisfaction and global satisfaction was especially strong for visitors traveling as part of a guided tour, as opposed to those traveling independently. Tour group visitors had consistently higher satisfaction levels than independent travellers both with interpretive and non-interpretive services and setting attributes, regardless of whether they were national or foreign tourists. Results also suggested that travel as part of a guided tour group could positively influence visitor satisfaction with a range of services and experience attributes. What they could not determine was whether tourist satisfaction was a function of the quality of the tourist guide, the content of the tour, the itinerary, the length of the trip, the interaction with group members during the tour, or some other aspects of the guided tour. However, previous research on guided tours has supported the notion that it is the presence and quality of the tourist guide that most influences visitor satisfaction with guided tours (Ham \& Weiler, 2002; 2007; Weiler \& Ham, 2001).

Guided tours involve more than referring to physical objects and memorizing historical facts and data. They are non-standard complex services dependent on the education, interests, and individual talents of the guide (Zillinger et al., 2012).

\section{Conceptual Framework and Hypotheses}

Based on Hwang, Lee, and Chen's (2005) relationship model, the framework model used in this study proposes a research that relates tourist guide performance and destination image in which the role of satisfaction with the guided tour is examined. Figure 1 presents the tour guide performance correlational model.

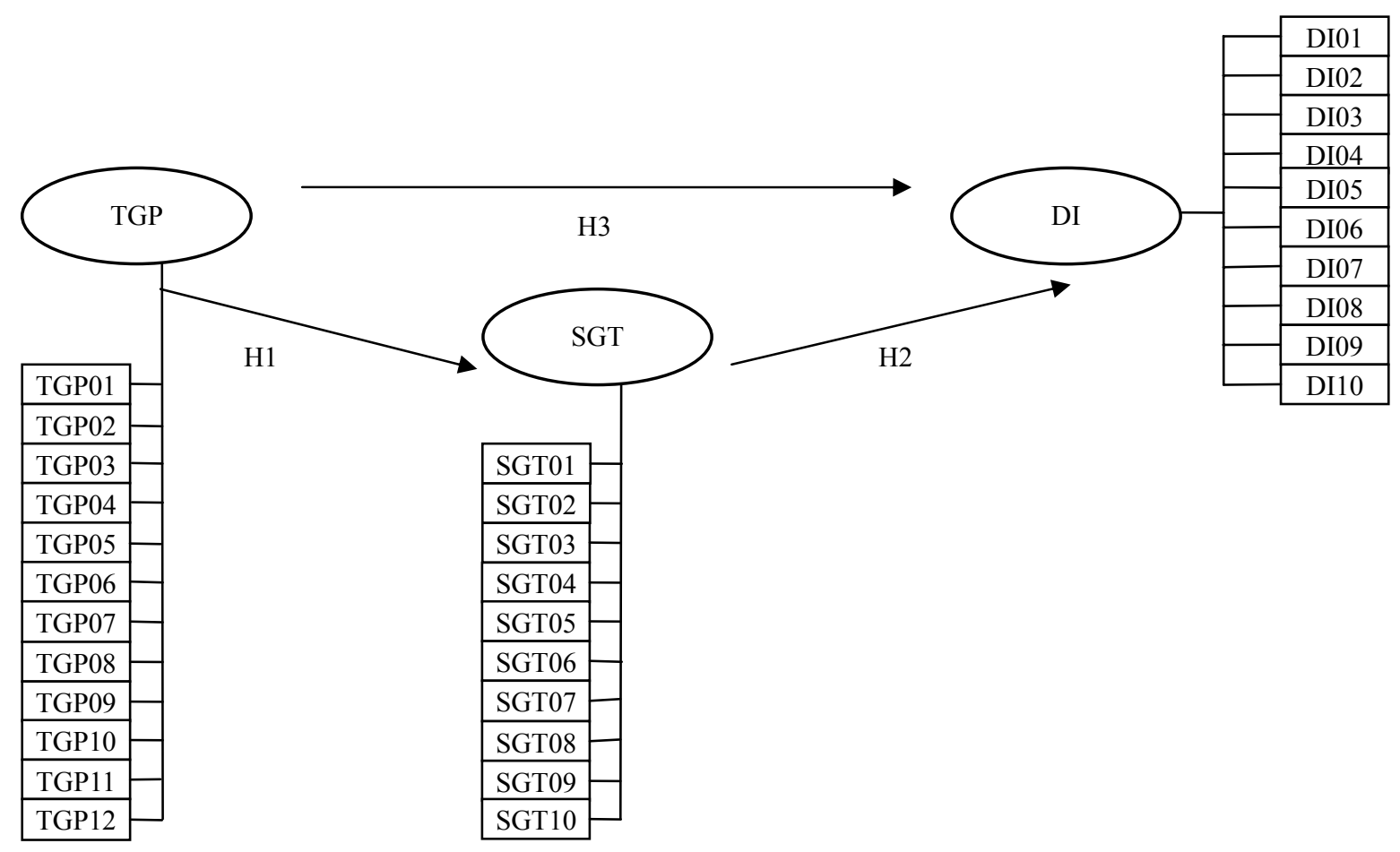

Figure 1. Research framework. 
Accordingly, three hypotheses are made as follows:

H1: Tourist guide performance has a positive effect on tourist's satisfaction with guided tours.

H2: Tourist's satisfaction with guided tours has a positive effect on tourist's perceived destination image.

H3: Tourist guide performance has a positive effect on tourist's perceived destination image.

\section{Research Methods}

Several authors address the issue of tourist destination components as the main elements characterizing and differentiating a TDI. They have identified a set of variables/image components of tourist destinations, empirically studied, through different supply models, seeking to characterize the image that a tourist has about a particular destination.

Taking on all previous arguments and assuming live tourist experience as the most reliable way of collecting information, 10 variables of destination image (see Table 9) were defined and touring tourists' opinion that travelled along Portugal, for more than four days, escorted by a tourist guide, was surveyed. For that tourists' satisfaction with the guided tour, expectations about the professional competences of their guide, and tourist guide's influence on tourist's individual opinion about Portugal's image have been inquired. Data also allowed tracing a socio-demographic profile of the touring tourists in Portugal.

\section{Questionnaire Design}

The sampling period lasted for 10 months (from September 2013 to July 2014), and a total of 300 questionnaires were distributed to tourist guides. A descriptive study was fulfilled with data collected through a questionnaire, applied to touring tourists on the last day of their visit to Portugal, obtaining a sample of 250 questionnaires. This analysis relies mainly on partial data obtained from an extended survey undertaken for a Ph.D. thesis consisting in a more comprehensive study of the role of tourist guides in the tourist experience. The survey yielded 210 valid responses. Given the number of tourists visiting Portugal by coach tour, accompanied by a tourist guide, and the type of statistical analysis used, the sample size can be considered representative.

Tourists in package tours were the sampling targets, on group tours composed of at least five persons. A package tour is arranged by a travel agent, who charges an inclusive price for transportation, food, and lodging services (K. C. Chang, 2014). In Portugal, tourist guides commonly guide inbound tourists or domestic travellers on package tours. Accordingly, Portuguese tourist guides who lead tours for tourists from several foreign countries were invited to distribute the questionnaires. A brief written explanation was given to the tourist guides on how to conduct the questionnaire. Although the sample is large enough for the application of parametric tests, non-parametric tests were used because there is no homoscedasticity of distribution. The tests were performed with $95 \%$ confidence.

The back-translation method proposed by Sinaiko and Brislin (1973) was used to ensure the quality of the translation; therefore, the questionnaire was translated from Portuguese to English, French, German, Italian, and Spanish. The tourist guides distributed the questionnaires to the tourists on the last night of the tour in the hotel. To prevent response biases from tour members who may think that the tourist guide would see their answers, the completed questionnaire could be placed in an arranged place and picked up later by the tourist guide. In addition, the tourist guide would inform the tour members that only the researchers would see the returned questionnaires. 


\section{Measurement}

A 5-point semantic differential scale (i.e., completely satisfied/very dissatisfied, surpassed expectations/worse than expected, and change opinion extremely/not at all changed opinion) was used for all the satisfaction measurements. The tourist's satisfaction construct towards the tour was adopted from past research (Mossberg, 1995) and included 10 items, measured on a 3-point semantic differential scale (less/about/more than expected). The tourist guide performance construct used was adapted from previous research (K. C. Chang, 2014) and included 12 items measuring the service quality of tourist guide performance. Each variable was measured on a 5-point Likert scale, ranging from $1=$ "worse than expected" to 5 = "surpassed expectations". These ordinal scales were converted into quantitative scales whereas the lower range would assume zero, growing one for each of the following value scale. This transformation has enabled the use of averages as an indicator for evaluation of the issues. Finally, the demographic characteristics of respondents (gender, age, and country of residence) were measured as categorical variables.

A careful review by experts (both academics and practitioners) in the field ensured the validity of the content of the instrument. A pilot survey has been conducted, sampling a group of 16 coach tour tourists that were touring in Portugal. The first version of the questionnaire tested proved that all the questions were understood by respondents in the same way and in the manner intended by the researcher and that respondents did not consider the survey too long, boring, or difficult. These findings justified the reliability and validity of the questionnaire.

\section{Findings and Discussion}

\section{Descriptive Analysis}

Profile of the respondents. A total of 300 questionnaires were distributed to respondents, and 250 were collected, representing a response rate of $83 \%$. Of the returned questionnaires, 210 were usable.

The socio-demographic profile (gender, age, qualifications, and country of residence) of the respondents is presented in Tables 1-4.

Table 1

Gender

\begin{tabular}{llccc}
\hline & Gender & Frequency & Valid percent (\%) & Cumulative percent (\%) \\
\hline Valid & Female & 131 & 62.4 & 62.4 \\
& Male & 79 & 37.6 & 100.0 \\
& Total & 210 & 100.0 & \\
\hline
\end{tabular}

Table 2

Age

\begin{tabular}{llccc}
\hline & Age & Frequency & Valid percent (\%) & Cumulative percent (\%) \\
\hline Valid & 18 or less & 1 & 0.5 & 0.5 \\
& $19-24$ & 2 & 1.0 & 1.4 \\
$25-34$ & 2 & 1.0 & 2.4 \\
$35-44$ & 13 & 6.2 & 8.6 \\
$45-54$ & 20 & 9.4 & 18.1 \\
$55-64$ & 65 & 31.0 & 49.0 \\
$65-74$ & 83 & 39.5 & 88.6 \\
75 or more & 24 & 11.4 & 100.0 \\
Total & 210 & 100.0 & \\
\hline
\end{tabular}


There were 131 (62.4\%) females and 79 (37.6\%) males among the respondents. The main age group was $65-74$, representing $39.5 \%$ of the respondents. The next three groups were 55-64 (31.0\%), 75 or more (11.4\%), and 45-54 (9.4\%). The remaining age groups only accounted for a minority of respondents, with $6.2 \%$ in the 35-44 age group, $1.0 \%$ in both the $25-34$ age group and $19-24$ age group, and $0.5 \%$ in the below 18 years old age group.

Table 3

Qualifications

\begin{tabular}{llccc}
\hline & Qualification & Frequency & Valid percent (\%) & Cumulative percent (\%) \\
\hline Valid & N/A & 1 & 0.5 & 0.5 \\
& Primary school & 17 & 8.1 & 8.6 \\
& Secondary school & 91 & 43.3 & 51.9 \\
University degree & 59 & 28.1 & 80.0 \\
Master & 29 & 13.8 & 93.8 \\
Ph.D. & 13 & 6.2 & 100.0 \\
Total & 210 & 100.0 & \\
\hline
\end{tabular}

Almost half of the respondents had college and university education, accounting for $48.1 \%$ of the total respondents, having $20 \%$ postgraduate education. Those with secondary school education represented $43.3 \%$ of the respondents, while $8.1 \%$ had primary school education.

Table 4

Country of Residence

\begin{tabular}{llccc}
\hline & Country & Frequency & Valid percent (\%) & Cumulative percent (\%) \\
\hline Valid & Germany & 25 & 11.9 & 11.9 \\
& Brazil & 24 & 11.4 & 23.3 \\
& USA & 43 & 20.5 & 43.8 \\
& France & 2 & 1.0 & 44.8 \\
& Italy & 115 & 54.7 & 99.5 \\
& Switzerland & 1 & 0.5 & 100.0 \\
& Total & 210 & 100.0 & \\
\hline
\end{tabular}

As for their geographical distribution, the great majority of travellers come from Europe (68.1\%), with Italy at a pole position with $54.7 \%$ of all respondents. From overseas, Portugal received $11.4 \%$ of Brazilians and $20.5 \%$ of North American touring tourists.

Data also allowed understanding the travelling habits of the coach tour tourists inquired. Table 5 shows the number of visits to Portugal and Table 6 proves that these tourists are used to travel with tourist guides.

Table 5

Number of Visits

\begin{tabular}{llccc}
\hline & Number of visits & Frequency & Valid percent (\%) & Cumulative percent (\%) \\
\hline Valid & N/A & 1 & 0.5 & 0.5 \\
& First time & 199 & 94.7 & 95.2 \\
& $2-5$ times & 10 & 4.8 & 100.0 \\
Total & 210 & 100.0 & \\
\hline
\end{tabular}


Regarding the number of visits to Portugal, the great majority $(94.7 \%)$ were first-time travellers to Portugal, whereas $4.8 \%$ of the respondents had been to Portugal 2-5 times.

Table 6

Travelled With Tourist Guide in the Last Three Years

\begin{tabular}{llccc}
\hline & Travelled with a guide & Frequency & Valid percent (\%) & Cumulative percent (\%) \\
\hline Valid & First time & 50 & 23.8 & 23.8 \\
& Always & 117 & 55.7 & 79.5 \\
& Another & 43 & 20.5 & 100.0 \\
& Total & 210 & 100.0 & \\
\hline
\end{tabular}

As many as $55.7 \%$ of the respondents were experienced travellers with guided tours and always travelled with a tourist guide during the last three years.

Tourist's satisfaction with guided tours' attributes. The Expectancy Disconfirmation Paradigm (EDP) holds that consumer satisfaction or dissatisfaction is a function of the disconfirmation arising from discrepancies between prior expectations and actual performance. Higher performance relative to expectations results in satisfaction, and vice versa (Weber, 1997). When the anticipated service, i.e., tourist expectation, is greater than the perceived service, the perceived quality will be higher or better than satisfactory. Thus, when tourist expectations are high, tourists are more likely to evaluate the tour quality less favourably (Lee, Jeon, \& Kim, 2011).

Table 7

Tourists'Satisfaction With Guided Tour's Attributes

\begin{tabular}{lclll}
\hline Attribute & Less than expected (\%) & As expected (\%) & More than expected (\%) & Mean \\
\hline Initial prog. & 2.0 & 65.3 & 32.7 & 1.31 \\
Changes pr. & 5.5 & 66.1 & 28.4 & 1.23 \\
Bus time & 4.0 & 78.3 & 17.7 & 1.14 \\
Stay time & 7.0 & 76.9 & 16.1 & 1.09 \\
Stops freq. & 1.0 & 80.8 & 18.2 & 1.17 \\
Bus comfort & 3.0 & 64.4 & 32.7 & 1.30 \\
Bus driver & 1.0 & 37.3 & 61.7 & 1.61 \\
Local people & 12.2 & 68.0 & 19.9 & 1.08 \\
Timetables & 3.2 & 76.2 & 20.6 & 1.17 \\
Places & 1.5 & 42.1 & 56.3 & 1.55 \\
\hline
\end{tabular}

In order to address the expectations of tour quality attributes by foreign touring tourists, the means were calculated. The survey results were presented according to the ranking of the mean scores (see Table 7).

All the 10 guided tour's attributes had a mean score of 1.27, ranging from 1.08 to 1.61 , denoting that touring tourists ranked all them between "as expected" and "more than expected". The top three most important variables were "professional competence of the bus driver" $(\mathrm{M}=1.61)$, "interest of places you have visited" $(\mathrm{M}=1.55)$, and "compliance with initial program" $(\mathrm{M}=1.31)$. Foreign tourists that toured in Portugal considered the competence of the bus driver, the interest of places they have visited, and compliance with initial program the most important attributes to contribute for a quality tour. These results can be explained, considering that safety issues related with bus and driver, places that can surprise them and no program changes during travel are critical features for senior tourists and group tours. 
Visitors expect their tourist guides to be experts on the destinations, so as to inform them and interpret the destinations in more depth (Zhang \& Chow, 2004). Being so, it is understandable why "duration of stay in places visited" $(M=1.09)$ and "bus journey times" $(M=1.14)$ register the second and third more critical attributes with the tour. Directly connected with the need to spend more time on a visiting place and less time inside the bus, and corresponding to the lowest rating of all, what most frustrated the group's expectation was the lack of "contacts with local people" $(\mathrm{M}=1.08)$. In guided tours, and especially in an unfamiliar environment, generally, the tourist guide is the first and closest "contact person".

It was Holloway (1981) who pointed out that the guide's "representative" role in managing a tour group as well as his/her interpretation of attractions decrease chances for contacts with the local population, since guides function as a "buffer" between a group and outside influence or experience. The guide directs tourists where to go, what to see, and above all, how to interpret things they have seen.

As Rabotić (2010) explained, one of the reasons for peculiar "isolation" of tourists from the local setting is the very nature of guides' commentaries, as explanations sometimes given to tourists can differentiate substantially from those offered by local community members. The group's attention is focused towards inside, the guide, rather than outside, towards the site.

Tourist guide's performance attributes. Because tourist guides are the vital interface between the host destination and its visitors (Ap \& Wong, 2001), whether tourist guides can demonstrate quality services to tourists is not only beneficial to the business development of their travel agents but also critical to the overall image of the destination they represent (Huang et al., 2010). In other words, tourist guides bear a great responsibility for achieving tourist satisfaction through the services they provide (J. C. Chang, 2006; K. C. Chang, 2014).

The points for discussion covered in this section are far from exclusive, but are viewed as key issues or matters of significance. The 12 chosen variables can enhance tourist guide performance through one or a combination of several items (see Table 8).

Table 8

Tourist Guide Performance Attributes

\begin{tabular}{llllll}
\hline Attribute & $\begin{array}{l}\text { Lower than } \\
\text { expected (\%) }\end{array}$ & As expected (\%) & $\begin{array}{l}\text { Better than } \\
\text { expected (\%) }\end{array}$ & $\begin{array}{l}\text { Surpassed } \\
\text { expectations (\%) }\end{array}$ & Mean \\
\hline History & 0.0 & 15.8 & 34.0 & 50.2 & 3.34 \\
Geography & 0.0 & 21.3 & 35.3 & 43.5 & 3.22 \\
Popular cult. & 0.0 & 15.9 & 35.7 & 48.3 & 3.32 \\
Leisure tq & 2.2 & 30.1 & 37.2 & 30.6 & 2.96 \\
Group tq & 1.0 & 21.2 & 37.3 & 40.4 & 3.17 \\
Etiquette & 0.6 & 21.3 & 35.1 & 43.1 & 3.21 \\
First-aid & 2.2 & 37.2 & 31.4 & 29.2 & 3.88 \\
Leader & 0.0 & 16.3 & 35.5 & 48.3 & 3.38 \\
Empathetic & 0.5 & 14.1 & 31.8 & 53.5 & 3.33 \\
Articulated & 0.5 & 14.4 & 36.8 & 48.3 & 3.19 \\
Quiet & 1.5 & 21.5 & 33.3 & 43.6 & 3.21 \\
Ethical & 0.5 & 19.7 & 38.3 & 41.5 & \\
\hline
\end{tabular}


The mean scores of the tourist guide performance statements on 12 attributes were calculated. The survey results are reported in Table 8. It was shown that the mean scores for all the 12 skills ranged from 3.38 to 2.88 . All the 12 statements had a standard mean of 3.21. Six of them rated higher than average corresponding to very positive perceived expectations about the guide's performance.

Touring tourists in Portugal gave the top ratings to "being empathetic and expressive in communication, reasoning with logic and in a clear way" $(\mathrm{M}=3.38)$, followed by "knowledge of history" $(\mathrm{M}=3.34)$, "speaking in an articulated manner and without language vices" $(\mathrm{M}=3.33)$, and both "knowledge of art and popular culture" $(M=3.32)$ and "being a leader, determined, enterprising, practical, dynamic, and active" $(M=3.32)$.

Personal traits of character, good communication, and knowledge in either history or art were considered by the coach touring tourists who visited Portugal very important. Since its foundation, Portugal has been gathering heritage treasures, natural or manmade, and when visiting it, cultural touring tourists appreciate an agreeable and knowledgeable tourist guide.

The tourist guides' professional competencies were perceived as less satisfactory in the aspects of "knowledge of first-aid procedures" $(\mathrm{M}=2.88)$, not because that the tourist guides did not know how to deal with these procedures but that, luckily, they were not necessary. "Mastering entertainment and leisure techniques" $(\mathrm{M}=2.96)$ was also considered irrelevant to maintain and keep up the good service standards of tour guiding.

The possible outcomes of implementing some or all of these variables not only improve individual guide performance and industry-wide performance but also enhance visitor experience (Black \& Weiler, 2005). One of the aspects particularly influential on the tour experience is presentation (commentary), apart from managing group dynamics. The quality of commentary should be a combination of informative and entertainment contents, adapted to the clients' interests and presented enthusiastically, encouraging guide-tourist interaction, as well as the interaction within a tourist group. This justifies the reason why tourists rated so high "being empathetic and expressive in communication, reasoning with logic and in a clear way" and "speaking in an articulated manner".

The empirical research of McDonnell (2001) shows that participants of the guided tour are interested in the daily life of a destination as well as the tradition of local community $(\mathrm{M}=3.32)$, apart from its history $(\mathrm{M}=3.34)$ and separate attractions. Results confirm the existing research.

Tourists also see as an important function of a tourist guide the responsibility for the group and relationship among its members, a reason why they rated "being a leader, determined, enterprising, practical, dynamic, and active" $(\mathrm{M}=3.32)$ as a very important attribute after communication and knowledge. Successful management of group dynamics represents the guarantee for achieving a certain degree of satisfaction among the tour participants (Quiroga, 1990).

The guide's influence can only be understood in the tourist experience if the role is assumed as a connector, whose presence is necessary but discrete, whose knowledge is evident without being imposing, whose energy is indispensable without tiring anyone, and whose character is decided without being kind. The guide's performance influence varies according to several aspects. Time is probably the most important one, as it can work both ways. The longer the contact with the group, the better the interaction, or, by opposition, their relationship deteriorates. The field work that has been done and that will be mentioned next will prove the argument, considering the tourist guide performance as a key factor to the success of the tourist experience, hence of the tourist satisfaction and of Portugal destination image. 
Table 9

Tourist Guides' Influence on Destination Image Components

\begin{tabular}{lclllll}
\hline Component & Not at all (\%) & Slightly (\%) & Moderately (\%) & Very (\%) & Extremely (\%) & Mean \\
\hline Hospitality & 11.1 & 5.6 & 16.7 & 42.9 & 23.7 & 2.63 \\
Tour. info & 7.1 & 2.6 & 11.7 & 40.8 & 37.8 & 2.99 \\
Infrastruct. & 9.5 & 4.7 & 20.5 & 41.6 & 23.7 & 2.65 \\
Landscape & 8.8 & 2.1 & 17.6 & 42.0 & 29.5 & 2.81 \\
Beach & 15.8 & 7.3 & 18.1 & 37.9 & 20.9 & 2.41 \\
Gastronomy & 7.9 & 5.8 & 18.4 & 37.4 & 30.5 & 2.77 \\
Monuments & 7.8 & 2.6 & 10.9 & 38.5 & 40.1 & 3.01 \\
Act. nature & 24.7 & 9.6 & 21.9 & 32.2 & 11.6 & 1.97 \\
Money for value & 11.4 & 8.6 & 24.3 & 34.6 & 21.1 & 2.45 \\
Security & 11.9 & 3.8 & 22.7 & 34.1 & 27.6 & 2.62 \\
\hline
\end{tabular}

Tourist guides' influence on destination image components. Completing K. C. Chang's (2014) study, this analysis confirms that tourist guide attitude has positive effects on the credibility of the destination image. Half the image components score more than the mean of 2.63, as shown in Table 9. Ye and Tussyadiah (2011) have concluded from their study that visitors who are more inclined to touring tend to be inspired by images portraying a combination of different aspects of the destination, from natural scenery to landmark buildings to people in recreational activities.

It is understood from the analysis done that touring tourists in Portugal combine these three vectors as they recognized to be influenced by the tourist guide attitude in respect of "monuments/museums" $(\mathrm{M}=3.01)$, "tourist information" $(\mathrm{M}=2.99)$, "landscape" $(\mathrm{M}=2.81)$, "gastronomy and wines" $(\mathrm{M}=2.77)$, and "existing infrastructures (airport, accommodation, restaurants, etc.)" $(\mathrm{M}=2.65)$, to name the five most influenced components.

As was discussed in the previous section, the roles that a guide may be required to perform in order to facilitate a quality tourist experience point to a range of attitudes, knowledge, and skills that tourist guides need (Black \& Weiler, 2005). Using Echtner and Ritchie's (1993) taxonomies of psychological and functional components of destination image, the tourist guide's attitude exerts more influence on the psychological quadrant than on the functional one. This demonstrates that Portugal's destination image components are essentially intangible, proving a strong holistic nature (Hunt, 1975), summed up by touring tourists after opinions, ideas, and impressions, but mainly by their overall satisfaction with the tourist experience.

These more distinctive traits, composing its imagery, are enhanced by the tourist guide's professional skills and feelings, considering that what an individual thinks and feels about a destination is subjective and also the meaning he/she builds. This imagery seems to be shaped by the ambiance tourists are involved in and by the tourist guide's positive values and vision of his/her own country.

\section{Hypothesis Testing}

To corroborate previous descriptive findings and to verify if the guide's professional attributes had influenced the tourist's opinion about destination image components, a Kruskal-Wallis test was done, for each component, considering the following hypotheses for each variable:

$$
\begin{gathered}
\mathrm{H}_{0}: \tau_{1}=\tau_{2}=\ldots=\tau_{k} \\
\mathrm{H}_{1}: \exists^{1} \tau_{i} \neq \tau_{j} ; i, j=1 \ldots k
\end{gathered}
$$

where $\tau_{k}$ is the effect (the guide). 
The result of the test $(p$-value $<0.05)$ indicates that null hypothesis in all variables should be rejected, except for the variables SGT01, SGT05, TGP01, TGP02, and TGP08 (see Appendix for detailed definitions of the variables). Therefore, the tourist guide is a factor of influence on tourists' opinion about Portugal image. Moreover, correlations between the various components have been made and analysed. Tables 10, 11, and 12 show the nature of relations established between components.

Table 10

Correlation Between Tourist Guide Performance (TGP) and Satisfaction With Guided Tour (SGT)

\begin{tabular}{|c|c|c|c|c|c|c|c|c|c|c|c|c|}
\hline Component & $\begin{array}{l}\text { History } \\
\text { TGP01 }\end{array}$ & $\begin{array}{l}\text { Geography } \\
\text { TGP02 }\end{array}$ & $\begin{array}{l}\text { Popular } \\
\text { cult. } \\
\text { TGP03 }\end{array}$ & $\begin{array}{l}\text { Leisure } \\
\text { tq } \\
\text { TGP04 }\end{array}$ & $\begin{array}{l}\text { Group } \\
\text { tq } \\
\text { TGP05 }\end{array}$ & $\begin{array}{l}\text { Etiquette } \\
\text { TGP06 }\end{array}$ & $\begin{array}{l}\text { First-aid } \\
\text { TGP07 }\end{array}$ & $\begin{array}{l}\text { Leader } \\
\text { TGP08 }\end{array}$ & $\begin{array}{l}\text { Empathetic } \\
\text { TGP09 }\end{array}$ & $\begin{array}{l}\text { Articulated } \\
\text { TGP10 }\end{array}$ & $\begin{array}{l}\text { Quiet } \\
\text { TGP11 }\end{array}$ & $\begin{array}{l}\text { Ethical } \\
\text { TGP12 }\end{array}$ \\
\hline $\begin{array}{l}\text { Initial } \\
\text { prog. } \\
\text { SGT01 } \\
\end{array}$ & $0.146^{*}$ & $0.220^{* *}$ & $0.166^{*}$ & $0.220^{* *}$ & $0.238^{* *}$ & $0.204^{* *}$ & $0.293^{* *}$ & $0.178^{* *}$ & $0.238^{* *}$ & $0.309^{* * *}$ & $0.225^{* *}$ & $0.246^{* *}$ \\
\hline $\begin{array}{l}\text { Changes } \\
\text { pr. } \\
\text { SGT02 }\end{array}$ & 0.028 & $0.143^{*}$ & $0.159^{*}$ & $0.226^{* *}$ & $0.245^{* *}$ & $0.260^{* *}$ & $0.319^{* *}$ & 0 & $0.208^{* *}$ & $0.165^{*}$ & $0.163^{*}$ & $0.247^{* *}$ \\
\hline $\begin{array}{l}\text { Bus time } \\
\text { SGT03 }\end{array}$ & 0.086 & 0.127 & 0.103 & 0.132 & $0.241^{* *}$ & $0.238^{* *}$ & $0.173^{*}$ & 0.041 & $0.165^{*}$ & $0.161^{*}$ & 0.091 & $0.169^{*}$ \\
\hline $\begin{array}{l}\text { Stay time } \\
\text { SGT04 }\end{array}$ & 0.022 & 0.119 & 0.102 & $0.156^{*}$ & $0.174^{*}$ & $0.188^{* *}$ & $0.152^{*}$ & -0.003 & $0.185^{* *}$ & 0.112 & 0.053 & $0.199^{* *}$ \\
\hline $\begin{array}{l}\text { Stops freq. } \\
\text { SGT05 }\end{array}$ & 0.095 & 0.048 & 0.039 & $0.198^{* *}$ & $0.230^{* *}$ & $0.196^{* *}$ & $0.248^{* *}$ & 0.073 & $0.186^{* *}$ & $0.147^{*}$ & 0.09 & $0.213^{* *}$ \\
\hline $\begin{array}{l}\text { Bus } \\
\text { comfort } \\
\text { SGT06 } \\
\end{array}$ & $0.155^{*}$ & $0.192^{* *}$ & $0.217^{* *}$ & $0.196^{* *}$ & $0.210^{* *}$ & $0.329^{* *}$ & $0.276^{* *}$ & $0.149^{*}$ & $0.259^{* *}$ & $0.264^{* *}$ & $0.222^{* *}$ & $0.258^{* *}$ \\
\hline $\begin{array}{l}\text { Bus driver } \\
\text { SGT07 }\end{array}$ & $0.192^{\text {** }}$ & $0.217^{* *}$ & $0.277^{* *}$ & $0.204^{* *}$ & $0.277^{* *}$ & $0.318^{* *}$ & $0.209^{* * *}$ & $0.214^{* *}$ & $0.280^{* *}$ & $0.274^{* *}$ & $0.201^{* * *}$ & $0.278^{* *}$ \\
\hline $\begin{array}{l}\text { Local } \\
\text { people } \\
\text { SGT08 } \\
\end{array}$ & 0.023 & 0.076 & 0.092 & $0.222^{* *}$ & $0.223^{* *}$ & $0.338^{* *}$ & $0.255^{* *}$ & 0.034 & $0.225^{* *}$ & $0.142^{*}$ & $0.220^{* *}$ & $0.227^{* *}$ \\
\hline $\begin{array}{l}\text { Timetables } \\
\text { SGT09 }\end{array}$ & 0.037 & 0.045 & 0.115 & $0.308^{* *}$ & $0.298^{* *}$ & $0.231^{* *}$ & $0.272^{* *}$ & 0.109 & $0.244^{* *}$ & $0.213^{* * *}$ & $0.217^{* *}$ & $0.288^{* *}$ \\
\hline $\begin{array}{l}\text { Places } \\
\text { SGT10 }\end{array}$ & 0.072 & $0.177^{*}$ & $0.164^{*}$ & $0.209^{* *}$ & $0.234^{* *}$ & $0.240^{* *}$ & $0.232^{* *}$ & $0.174^{*}$ & $0.283^{* *}$ & $0.184^{* *}$ & $0.189^{* *}$ & $0.326^{* *}$ \\
\hline
\end{tabular}

Notes. ": Correlation is significant at the 0.05 level (2-tailed); ${ }^{* * *}$ : Correlation is significant at the 0.01 level (2-tailed). Strong green $($ gray in printed version $)=$ Strong correlation; Medium green $($ gray in printed version $)=$ Moderate correlation; Light green $($ gray in printed version $)=$ Weak correlation. Detailed definitions of TGP and SGT components can be seen in Appendix.

Table 11

Correlation Between SGT and Destination Image (DI)

\begin{tabular}{llllllllllll}
\hline Component & $\begin{array}{l}\text { Hospitality } \\
\text { DI01 }\end{array}$ & $\begin{array}{l}\text { Tour. } \\
\text { info } \\
\text { DI02 }\end{array}$ & $\begin{array}{l}\text { Infrastruct. Landscape } \\
\text { DI03 }\end{array}$ & DI04 & DI05 & $\begin{array}{l}\text { Gastronomy } \\
\text { DI06 }\end{array}$ & $\begin{array}{l}\text { Monuments } \\
\text { DI07 }\end{array}$ & $\begin{array}{l}\text { Act. } \\
\text { nature } \\
\text { DI08 }\end{array}$ & $\begin{array}{l}\text { Money for } \\
\text { value } \\
\text { DI09 }\end{array}$ & $\begin{array}{l}\text { Security } \\
\text { DI10 }\end{array}$ \\
\hline $\begin{array}{l}\text { Initial prog. } \\
\text { SGT01 }\end{array}$ & 0.093 & 0.085 & $0.163^{*}$ & $0.169^{*}$ & 0.082 & 0.088 & 0.129 & $0.167^{*}$ & 0.096 & $0.169^{*}$ \\
\hline $\begin{array}{l}\text { Changes pr. } \\
\text { SGT02 }\end{array}$ & 0.134 & 0.114 & $0.143^{*}$ & 0.109 & 0.12 & 0.042 & 0.065 & $0.147^{*}$ & 0.134 & 0.102 \\
\hline $\begin{array}{l}\text { Bus time } \\
\text { SGT03 }\end{array}$ & $0.149^{*}$ & 0.135 & $0.172^{*}$ & 0.075 & -0.02 & $0.137^{*}$ & $0.142^{*}$ & 0.055 & $0.141^{*}$ & 0.113 \\
\hline $\begin{array}{l}\text { Stay time } \\
\text { SGT04 }\end{array}$ & 0.081 & 0.094 & $0.152^{*}$ & -0.003 & -0.03 & 0.016 & 0.058 & 0.053 & 0.104 & 0.075 \\
$\begin{array}{l}\text { Stops freq. } \\
\text { SGT05 }\end{array}$ & $0.155^{*}$ & 0.094 & $0.148^{*}$ & 0.079 & 0.044 & $0.149^{*}$ & 0.077 & 0.13 & 0.103 & 0.071 \\
\hline
\end{tabular}


(Table 11 continued)

\begin{tabular}{|c|c|c|c|c|c|c|c|c|c|c|}
\hline Component & $\begin{array}{l}\text { Hospitality } \\
\text { DI01 }\end{array}$ & $\begin{array}{l}\text { Tour. } \\
\text { info } \\
\text { DI02 }\end{array}$ & $\begin{array}{l}\text { Infrastruct. } \\
\text { DI03 }\end{array}$ & $\begin{array}{l}\text { Landscape } \\
\text { DI04 }\end{array}$ & $\begin{array}{l}\text { Beach } \\
\text { DI05 }\end{array}$ & $\begin{array}{l}\text { Gastronomy } \\
\text { DI06 }\end{array}$ & $\begin{array}{l}\text { Monuments } \\
\text { DI07 }\end{array}$ & $\begin{array}{l}\text { Act. } \\
\text { nature } \\
\text { DI08 }\end{array}$ & $\begin{array}{l}\text { Money for } \\
\text { value } \\
\text { DI09 }\end{array}$ & $\begin{array}{l}\text { Security } \\
\text { DI10 }\end{array}$ \\
\hline $\begin{array}{l}\text { Bus comfort } \\
\text { SGT06 }\end{array}$ & 0.117 & 0.086 & $0.221^{* *}$ & 0.086 & 0.077 & $0.192^{* *}$ & $0.180^{* *}$ & $0.162^{*}$ & $0.149^{*}$ & $0.228^{* *}$ \\
\hline $\begin{array}{l}\text { Bus driver } \\
\text { SGT07 }\end{array}$ & $0.172^{*}$ & 0.091 & $0.158^{*}$ & 0.08 & 0.03 & $0.166^{*}$ & $0.137^{*}$ & 0.119 & 0.091 & $0.223^{* *}$ \\
\hline $\begin{array}{l}\text { Local people } \\
\text { SGT08 }\end{array}$ & 0.109 & $0.148^{*}$ & $0.210^{* *}$ & $0.146^{*}$ & 0.066 & 0.101 & 0.129 & $0.146^{*}$ & $0.155^{*}$ & $0.155^{*}$ \\
\hline $\begin{array}{l}\text { Timetables } \\
\text { SGT09 }\end{array}$ & 0.099 & $0.208^{* * *}$ & $0.215^{* *}$ & 0.125 & 0.041 & 0.089 & $0.187^{* *}$ & 0.108 & $0.154^{*}$ & $0.177^{*}$ \\
\hline $\begin{array}{l}\text { Places } \\
\text { SGT10 } \\
\end{array}$ & 0.093 & 0.088 & $0.166^{*}$ & 0.134 & 0.001 & 0.076 & $0.164^{*}$ & 0.093 & 0.064 & 0.12 \\
\hline
\end{tabular}

Table 12

Correlation Between TGP and DI

\begin{tabular}{|c|c|c|c|c|c|c|c|c|c|c|}
\hline Component & $\begin{array}{l}\text { Hospitality } \\
\text { DI01 }\end{array}$ & $\begin{array}{l}\text { Tour. } \\
\text { info } \\
\text { DI02 }\end{array}$ & $\begin{array}{l}\text { Infrastruct. } \\
\text { DI03 }\end{array}$ & $\begin{array}{l}\text { Landscape } \\
\text { DI04 }\end{array}$ & $\begin{array}{l}\text { Beach } \\
\text { DI05 }\end{array}$ & $\begin{array}{l}\text { Gastronomy } \\
\text { DI06 }\end{array}$ & $\begin{array}{l}\text { Monuments } \\
\text { DI07 }\end{array}$ & $\begin{array}{l}\text { Act. } \\
\text { nature } \\
\text { DI08 }\end{array}$ & $\begin{array}{l}\text { Money for } \\
\text { value } \\
\text { DI09 }\end{array}$ & $\begin{array}{l}\text { Security } \\
\text { DI10 }\end{array}$ \\
\hline $\begin{array}{l}\text { History } \\
\text { TGP01 }\end{array}$ & $0.304^{* *}$ & $0.357^{* *}$ & $0.191^{* *}$ & $0.307^{\text {** }}$ & 0.133 & $0.287^{* *}$ & $0.349^{* *}$ & 0.072 & 0.121 & $0.208^{* *}$ \\
\hline $\begin{array}{l}\text { Geography } \\
\text { TGP02 }\end{array}$ & $0.380^{* *}$ & $0.419^{* *}$ & $0.357^{* *}$ & $0.419^{* * *}$ & $0.227^{* *}$ & $0.349^{* *}$ & $0.388^{* *}$ & $0.148^{*}$ & $0.226^{* *}$ & $0.289^{* *}$ \\
\hline $\begin{array}{l}\text { Popular cult. } \\
\text { TGP03 }\end{array}$ & $0.255^{* *}$ & $0.355^{* *}$ & $0.268^{* *}$ & $0.290^{* *}$ & $0.150^{*}$ & $0.268^{* *}$ & $0.366^{* *}$ & 0.106 & $0.135^{*}$ & $0.194^{* *}$ \\
\hline $\begin{array}{l}\text { Leisure tq } \\
\text { TGP04 }\end{array}$ & $0.191^{* *}$ & $0.259^{* *}$ & $0.252^{* *}$ & $0.234^{\text {** }}$ & $0.172^{*}$ & $0.237^{* *}$ & $0.261^{* *}$ & $0.350^{* *}$ & $0.293^{* *}$ & $0.305^{* *}$ \\
\hline $\begin{array}{l}\text { Group tq } \\
\text { TGP05 }\end{array}$ & $0.276^{* *}$ & $0.321^{* *}$ & $0.286^{* *}$ & $0.332^{* *}$ & $0.209^{* *}$ & $0.332^{* *}$ & $0.343^{* *}$ & $0.200^{* *}$ & $0.328^{* *}$ & $0.323^{* *}$ \\
\hline $\begin{array}{l}\text { Etiquette } \\
\text { TGP06 }\end{array}$ & $0.241^{* *}$ & $0.330^{* *}$ & $0.304^{* *}$ & $0.280^{* *}$ & $0.183^{* *}$ & $0.327^{* *}$ & $0.318^{* *}$ & $0.226^{* *}$ & $0.328^{* *}$ & $0.301^{* *}$ \\
\hline $\begin{array}{l}\text { First-aid } \\
\text { TGP07 }\end{array}$ & $0.162^{*}$ & $0.194^{* *}$ & $0.254^{* *}$ & $0.194^{* *}$ & $0.182^{* *}$ & $0.199^{* *}$ & $0.231^{* *}$ & $0.359^{* *}$ & $0.333^{* *}$ & $0.355^{* *}$ \\
\hline $\begin{array}{l}\text { Leader } \\
\text { TGP08 }\end{array}$ & $0.184^{* *}$ & $0.241^{* *}$ & $0.213^{* *}$ & $0.283^{* *}$ & 0.087 & $0.298^{* *}$ & $0.291^{* *}$ & 0.072 & $0.211^{* *}$ & $0.264^{* *}$ \\
\hline $\begin{array}{l}\text { Empathetic } \\
\text { TGP09 }\end{array}$ & $0.215^{* *}$ & $0.291^{* *}$ & $0.300^{* *}$ & $0.258^{* *}$ & 0.087 & $0.292^{* *}$ & $0.340^{* *}$ & 0.09 & $0.212^{* *}$ & $0.218^{* *}$ \\
\hline $\begin{array}{l}\text { Articulated } \\
\text { TGP10 }\end{array}$ & $0.237^{* *}$ & $0.342^{* *}$ & $0.263^{* *}$ & $0.337^{* *}$ & $0.186^{* *}$ & $0.300^{* *}$ & $0.396^{* *}$ & $0.170^{*}$ & $0.240^{* *}$ & $0.319^{* *}$ \\
\hline $\begin{array}{l}\text { Quiet } \\
\text { TGP11 }\end{array}$ & $0.256^{* *}$ & $0.283^{* *}$ & $0.220^{* *}$ & $0.267^{* *}$ & $0.169^{*}$ & $0.180^{* *}$ & $0.261^{* *}$ & $0.202^{* *}$ & $0.286^{* *}$ & $0.266^{* *}$ \\
\hline $\begin{array}{l}\text { Ethical } \\
\text { TGP12 }\end{array}$ & $0.267^{* *}$ & $0.337^{* *}$ & $0.350^{* *}$ & $0.335^{* *}$ & $0.250^{* *}$ & $0.248^{* *}$ & $0.391^{* *}$ & $0.195^{* *}$ & $0.324^{* *}$ & $0.299^{* *}$ \\
\hline
\end{tabular}

Notes.": Correlation is significant at the 0.05 level (2-tailed); ${ }^{* * *}$ : Correlation is significant at the 0.01 level (2-tailed). Strong green $=$ Strong correlation; Medium green $=$ Moderate correlation; Light green $=$ Weak correlation. Detailed definitions of DI and TGP components can be seen in Appendix.

Tourist guide performance has a significant and positive effect on tourist's satisfaction with guided tours. As it was discussed in the first part of this paper, the roles that a guide may be required to perform in order to facilitate a quality tourist experience point to a range of skills, attitudes, and knowledge that tourist guides need. The results point out that tourist guide performance has a significant and positive effect on tourist's satisfaction with guided tour (see Table 10). A quality guided tourist experience can, thus, be defined 
as an experience that fulfils the tourists' needs and meets or exceeds their expectations without compromising the long-term viability and sustainability of host cultures and environments (Black \& Weiler, 2005). Tourist satisfaction can be measured according to different variables, but for touring tourists, operational conditions of the tour are less influential than the guide's performance in their overall satisfaction. If the professional services of the guide do not meet the desirable standards, consequently all the members of the group will resent with that, and the tourist experience may be badly rated, corresponding to overall tourist dissatisfaction. On the other hand, if tourists are satisfied with everything they live during their visit, and satisfaction is a very immediately state of spirit, then a long queue of satisfactory episodes can make the tourist experience unforgettable.

Tourist's satisfaction with guided tours has a low significant and weak effect on tourist's perceived destination image. The results in Table 11 indicate that the perceptions held by tourists about tour organization demonstrated a very weak correlation with tourist's opinion about Portugal. Tourist satisfaction with the guided tour is not solely the obligation of the professionals in situ, as travel agencies are responsible for planning the itinerary and providing all preferable services to tourists, being all essential ingredients for good service quality (K. C. Chang, 2014). Nevertheless, the impact of service satisfaction on destination image is not very significant and its effect on destination image is weak, exception made for "security", "culture", and "infrastructures".

Tourist guide performance has a very significant and positive effect on tourist's perceived destination image. At the transaction level, expectation is the affective psychological response to a destination, while service quality is a cognitive belief about the destination's features or attributes. Both overall guided tour service quality and overall satisfaction are attitudes with cognitive and affective components that compose the problematic of TDI. As the analysis of Table 12 points out, Portugal's destination image is much more influenced by psychological components than functional ones. The tourist guide performance has a very significant and positive effect on tourist's perceived destination image about Portugal, in all its 10 components, being the influence lower in respect to "beaches" and "activities in nature" as coach tour tourists devaluated the two variables.

It seems that in estimating what makes a "good" guide, there is nothing controversial, still employers, clients, and guides themselves have different perceptions on the significance and priorities of particular qualities. Some of these are so vague and fluid that it is not easy to define them, let alone measure them. The nature of contact with clients, and the high level of interaction it entails, influences tourists' perceptions on guides' performance. Additionally, the results of the study confirm the conclusions of Beerli, Díaz, and Pérez (2002), who determined that the affective image has a greater influence on the overall image formation, as opposed to the cognitive image of service quality.

This result points to an important hedonic component in the purchase of a tourism destination, as the image formed is more dependent on the emotions of the individual towards the place, influenced by the attitude of the tourist guide they travel with, than on the cognitive evaluation of its characteristics.

It can be assumed that this hedonic component of images will influence the number and nature of guided tours designed and promoted by tour operators in Portugal. A negative image decreases the attractiveness of the destination and hinders the process of promoting and choosing of that destination, which turns detrimental to the local economy (Almeida et al., 2012). Specifically, it determines the strategic importance of cultural touring for the development of sustainable tourism in Portugal. 


\section{Conclusions}

This study developed a model to shed light on the issue of how tourist guide performance and tourist's satisfaction with the guided tour would influence tourists' perceived destination image. Coach tour foreign tourists travelling in Portugal were used as research subjects to give tourist guides important information about the relationships between tourist guide services, including the guided tour organization, and tourist satisfaction with his/her visiting experience, hence with the visited tourism destination. This information can be used to encourage tourist return, as it is known that marketing studies state that a well satisfied tourist recommends that destination and possible revisits it. Word-for-mouth is the most trustful tool in tourism destination marketing. The results engender some important implications which are discussed below, mainly in one of the most promising tourist products in Portugal: cultural touring.

First, the results of this study support previous research indicating that tour guide performance significantly affects tourist satisfaction (Huang et al., 2010). Nevertheless, although the tour guides' performances were generally quite satisfactory, results suggest that room for improvement remains in at least two areas. According to the average scores of the tour guide performance $(\mathrm{M}=3.21)$, some areas of the tour guides' performance, such as "knowledge of first-aid procedures" $(\mathrm{M}=2.88)$ and "mastering entertainment and leisure techniques" $(\mathrm{M}=2.96)$, were lower than other areas, indicating that these services must be improved to meet tourists' expectations. In other words, although some service constructs are simple and basic, they are the cornerstones of tourist guide performance and of high-quality services. This is not solely the obligation of the guides themselves, as travel agencies are also responsible for requiring their tour guides to provide preferable services to tourists.

Second, the findings of this study complement the extant literature by demonstrating that when tourists are satisfied with the operational aspects of a guided tour, they are more likely to engage in those attributes that transmit emotions and positive feelings towards the culture and way of life of the visited country, identifying sources of differentiation and improvement of the destination image. Nevertheless, this finding leads to another important discussion that although satisfaction is an important mediating variable between tour guide performance and destination image, the effect on destination image is low, being essentially (in)formed by the tourist guide performance. Therefore, compared with the other routes in the model, satisfaction with the guided tour has the weakest effect on the country's destination image (effect: -0.027).

Accordingly, the findings yield managerial insights for travel agencies and tour guides: Although satisfaction with the guided tour and tourist guide performance are both important outcomes for moulding destination image, it is important for tour guides to understand that tourists perceive the guided tour in a cognitive dimension, which is the rational analysis of its measurable attributes, differently from the tourist guide performance which refers to the affective dimension and the visitor's feelings towards it. Therefore, even though professional organizational services during a trip remain a good means of enhancing a tourism destination, the affective dimension of the tourist/guide relationship and the perception of credibility that is brought forth constitute the most reliable attributes forming a TDI.

Finally, the findings of this study demonstrate that tourist guide performance has a very strong correlation with destination image. Therefore, the inter-relationship of the cognitive component with the affective results in the conative component (Baloglu \& McCleary, 1999) supported by a growing trust between the tour guide and tourists during the trip, which could cause the tourists to experience more flow, intensifies their relational 
practice and increase the enjoyment of their itinerary, on an organized team gazing, thereby shaping their destination image. This conclusion might be explained by the fact that tourist guide performance surpassed tourists' expectations with the communicative function ("being empathetic and expressive in communication" and "speaking in an articulated manner without language vice") and scholar knowledge ("history, art, and popular culture") of the guide to be particularly influential on the tour experience.

Tourist guide performance is based on the tour guide's fulfilling several functions (K. C. Chang, 2014) and results point out that the guide's attitude changed tourist's opinion about Portugal, in relation to all 10 assessed components. In other words, these conative components of the country image may influence the number and nature of guided tours designed and promoted by tour operators in Portugal. A negative image decreases the attractiveness of the destination and while tourists may evaluate each element separately, dissatisfaction with one component leads to an overall negative evaluation of the destination as a whole (Assaker, Vinzi, \& O'Connor, 2011). Thus, in tourism, a destination image is holistic, and these findings might be crucial for the positioning and differentiation of Portugal as a tourism destination for coach tour tourists with tourist guides.

However, the findings reported here do suggest that interpretive services can add value to an experience that goes beyond visitors' satisfaction with the condition of physical infrastructure (Ham \& Weiler, 2007). In times of austerity, a frequent justification for not travelling in package tours with a tourist guide, omitting or eliminating interpretation, is that there just is not enough money to pay for touring and that what visitors want most are low-cost short-breaks. Moreover, this study proved that senior age is an important variable when preferring coach tour touring and bus safety, an attribute of vital importance for senior tourists' satisfaction with the guided tour which, subsequently, will influence their opinion about tourist guide performance and destination image.

Tourism usually contributes significantly to the economic development of a country, and Portugal is no exception. As this study proved, senior package tour tourists prefer to travel always with a tourist guide (55.7\%). Taking into account that, in 2013, senior population represented $12 \%$ of world population and will continue to increase in the next four decades to reach $21 \%$ in 2050 (United Nations, 2013), tourism stakeholders should empower professionals such as the tourist guides, treating and motivating them to become one of the stakeholders in tourism development (Rabotić, 2010).

The results obtained here are, therefore, useful to plan the development of Portugal as a better tourism destination and to design its marketing and promotional campaigns, as they identify sources of differentiation and improvement of the image of the destination. In this sense, it is important to focus on those attributes that transmit emotions and positive feelings towards the culture and way of life of the country.

\section{Limitations and Directions for Further Research}

This study's limitations provide directions for future study. First, this study focused on foreign coach tour tourists travelling with a tourist guide. Therefore, future studies should investigate different types of tourists (e.g., free and independent travel) to compare and validate the results of this research. Second, Matzler, Renzl, and Rothenberger (2006) found nationality to be an important mediator in the relationship between perceived service quality and related behavior. Therefore, tourists with different cultural backgrounds (such as visitors from Asia versus Europe, America versus Europe, or Asia versus America) may have different views on the performance of the tour guide, which would also influence their opinion about the visited country and perception 
about satisfaction with the guided tour. Third, although many important variables have been included in our model, it is important to realize that other factors may also play a critical role in the relationship between tour guide performance and destination image. For instance, future research might investigate how other factors, such as organic and induced image (Fakeye \& Crompton, 1991), would influence this relationship. Finally, this study was based on the respondents' answers that have been inquired during the visit, on the day before departure. Future research could use final results from pre-visits (tourists interested in coming to Portugal) and post-visits (tourists who have come to Portugal) to determine the complexity of Portugal destination image.

\section{References}

Almeida, P., Miranda, F. J., \& Elias-Almeida, A. (2012). Aplicação da análise importância-valor aos componentes da imagem de um destino turístico. Tourism and Management Studies, 8, 65-77.

Ap, J., \& Wong, K. K. F. (2001). Case study on tour guiding: Professionalism, issues, and problems. Tourism Management, 22(5), 551-563.

Assaker, G., Vinzi, V. E., \& O'Connor, P. (2011). Examining the effect of novelty seeking, satisfaction, and destination image on tourists' return pattern: A two factor, non-linear latent growth model. Tourism Management, 32(4), 890-901.

Baloglu, S. (1997). The relationship between destination images and sociodemographic and trip characteristics of international travelers. Journal of Vacation Marketing, 3(3), 221-233.

Baloglu, S., \& Brinberg, D. (1997). Affective images of tourism destinations. Journal of Travel Research, 35(4), 11-15.

Baloglu, S., \& McCleary, K. W. (1999). A model of destination image formation. Annals of Tourism Research, 26(4), 868-897.

Beerli, A., \& Martín, J. D. (2004). Factors influencing destination image. Annals of Tourism Research, 31(3), 657-681.

Beerli, A., Díaz, G., \& Pérez, P. (2002). The configuration of the university image and its relationship with the satisfaction of students. Journal of Education Administration, 40(5), 486-505.

Black, R. S., \& Weiler, B. (2005). Quality assurance and regulatory mechanisms in the tour guiding industry: A systematic review. Journal of Tourism Studies, 16(1), 24-37.

Chang, J. C. (2006). Customer satisfaction with tour leaders' performance: A study of Taiwan's package tours. Asia Pacific Journal of Tourism Research, 11(1), 97-116.

Chang, K. C. (2014). Examining the effect of tour guide performance, tourist trust, tourist satisfaction, and flow experience on tourists' shopping behavior. Asia Pacific Journal of Tourism Research, 19(2), 219-247.

Cohen, E. (1985). The tourist guide: The origins, structure, and dynamics of a role. Annals of Tourism Research, 12(1), 5-29.

Crompton, J. L. (1979). An assessment of the image of Mexico as a vacation destination and the influence of geographical location upon that image. Journal of Travel Research, 17(4), 18-23.

Dann, G. (1996). Tourists' images of a destination: An alternative analysis. Journal of Travel and Tourism Marketing, 5(1-2), 41-55.

Echtner, C. M., \& Ritchie, B. (1991). The meaning and measurement of destination image. The Journal of Tourism Studies, 14(1), $37-48$.

Echtner, C. M., \& Ritchie, B. (1993). The measurement of destination image: An empirical assessment. Journal of Travel Research, 31(4), 3-13.

Embacher, J., \& Buttle, F. (1989). A repertory grid analysis of Austria's image as a summer vacation destination. Journal of Travel Research, 27(3), 3-7.

European Committee for Standardization. (2003). European standard EN13809:2003 tourism services - Travel agencies and tour operators terminology.

Fakeye, P. C., \& Crompton, J. L. (1991). Image differences between prospective, first-time, and repeat visitors to the Lower Rio Grande Valley. Journal of Travel Research, 30(2), 10-16.

Gartner, W. C. (1986). Temporal influences on image change. Annals of Tourism Research, 13(4), 635-644.

Gil, S. M., Palacio, A. B., \& Santana, J. D. M. (2004). La imagen de Gran Canaria como destino turístico. Retrieved from http://www.fulp.eu/files/webfm/File/web/publicaciones/vectorplus/articulos/vp23_05_articulo05.pdf

Goodrich, J. N. (1978). The relationship between preferences for and perceptions of vacation destinations: Application of a choice model. Journal of Travel Research, 17(2), 8-13.

Gunn, C. A. (1988). Vacationscape: Designing tourist regions. New York, NY: Van Nostrand Reinhold. 
Gutiérrez, H. S. M. (2005). Estudio de la Imagen de Destino Turístico y el Proceso Global de Satisfacción: Adopción de un enfoque integrador (Ph.D. thesis, Departamento de Administración de Empresas, Universidad de Cantabria, Santander).

Ham, S., \& Weiler, B. (2002). Toward a theory of quality in cruise-based interpretive guiding. Journal of Interpretation Research, 7(2), 29-49.

Ham, S., \& Weiler, B. (2007). Isolating the role of on-site interpretation in a satisfying experience. Journal of Interpretation Research, 12(2), 5-24.

Holloway, J. C. (1981). The guided tour: A sociological approach. Annals of Tourism Research, 8(3), 377-402.

Huang, S., Hsu, C. H. C., \& Chan, A. (2010). Tour guide performance and tourist satisfaction: A study of the package tours in Shanghai. Journal of Hospitality and Tourism Research, 34(1), 3-33.

Hughes, K. (1991). Tourist satisfaction: A guided "cultural” tour in North Queensland. Australian Psychologist, 26(3), $166-171$.

Hunt, J. D. (1975). Image as a factor in tourism development. Journal of Travel Research, 13(3), 1-7.

Hwang, S. N., Lee, C., \& Chen, H. J. (2005). The relationship among tourists' involvement, place attachment, and interpretation satisfaction in Taiwan's national parks. Tourism Management, 26(2), 143-156.

Leclerc, D., \& Martin, J. N. (2004). Tour guide communication competence: French, German, and American tourists' perceptions. International Journal of Intercultural Relations, 28(3-4), 181-200.

Lee, S., Jeon, S., \& Kim, D. (2011). The impact of tour quality and tourist satisfaction on tourist loyalty: The case of Chinese tourists in Korea. Tourism Management, 32(5), 1115-1124.

Lopez, E. M. (1980). The effect of leadership style on satisfaction levels of tour quality. Journal of Travel Research, 18(4), 20-23.

Matzler, K., Renzl, B., \& Rothenberger, S. (2006). Measuring the relative importance of service dimensions in the formation of price satisfaction and service satisfaction: A case study in the hotel industry. Scandinavian Journal of Hospitality and Tourism, 6(3), 179-196.

McDonnell, I. (2001). The role of the tour guide in transferring cultural understanding. Working Paper No. 3, School of Leisure, Sport, and Tourism, University of Technology, Sydney. Retrieved from http://www.business.uts.edu.au/lst/downloads/WP03_McDonnell.pdf

McDowall, S. (2010). International tourist satisfaction and destination loyalty: Bangkok, Thailand. Asia Pacific Journal of Tourism Research, 15(1), 21-42.

Milman, A., \& Pizam, A. (1995). The role of awareness and familiarity with a destination: The central Florida case. Journal of Travel Research, 33(3), 21-27.

Min, J. C. H. (2012). A short-form measure for assessment of emotional intelligence for tour guides: Development and evaluation. Tourism Management, 33(1), 155-167.

Mossberg, L. L. (1995). Tour leaders and their importance in charter tours. Tourism Management, 16(6), 437-445.

Neves, J. M. D. O. (2012). Imagem de destino turístico: Contributo para uma sistematização da leitura científica. Retrieved from http://hdl.handle.net/10437/5237

Pearce, P. L. (1984). Tourist-guide interaction. Annals of Tourism Research, 11(1), 129-146.

Pereira, A. M., \& Cravidão, F. (2014). A coesão grupal no olhar do turista. Turismo and Desenvolvimento, 2(21/22), 425-439.

Pond, K. L. (1993). The professional guide: Dynamics of tour guiding. New York, NY: John Wiley \& Sons, Inc..

Quiroga, I. (1990). Characteristics of package tours in Europe. Annals of Tourism Research, 17(2), 185-207.

Rabotić, B. (2010). Tourist guides in contemporary tourism. Paper presented at the International Conference on Tourism and Environment, Sarajevo, March 4-5, 2010. Retrieved from http://www.belgradetours.com/THE\%20ROLE\%20OF\%20THE\%20TOURIST\%20GUIDE\%20IN.pdf

Schmidt, C. J. (1979). The guided tour: Insulated adventure. Journal of Contemporary Ethnography, 7(4), 441-467.

Scott, D. R., Schewl, C. D., \& Frederick, D. G. (1978). A multi-brand/multi-attribute model of tourist state choice. Journal of Travel Research, 17(3), 23-29.

Sinaiko, H. W., \& Brislin, R. W. (1973). Evaluating language translations: Experiments on three assessment methods. Journal of Applied Psychology, 57(3), 328-334.

Stabler, M. J. (1990). The image of destination regions: Theoretical and empirical aspects. In B. Goodall, \& G. Ashworth (Eds.), Marketing in the tourism industry: The promotion of destination regions (pp. 133-161). London: Routledge.

United Nations. (2013). World population ageing 2013. Department of Economic and Social Affairs Population Division. Retrieved from http://www.un.org/en/development/desa/population/publications/pdf/ageing/WorldPopulationAgeing2013.pdf

Urry, J., \& Larsen, J. (2011). The tourist gaze 3.0. London: Sage Publications. 
Wang, K. C., Hsieh, A. T., Chou, S. H., \& Lin, Y. S. (2007). GPTCCC: An instrument for measuring group package tour service. Tourism Management, 28(2), 361-376.

Weber, K. (1997). The assessment of tourist satisfaction using the expectancy disconfirmation theory: A study of the German travel market in Australia. Pacific Tourism Review, 1(1), 35-45.

Weiler, B., \& Ham, S. H. (2001). Tour guides and interpretation. In D. Weaver (Ed.), The encyclopedia of ecotourism (pp. 549-563). Wallingford, UK: CABI Publishing.

Ye, H., \& Tussyadiah, I. P. (2011). Destination visual image and expectation of experiences. Journal of Travel and Tourism Marketing, 28(2), 129-144.

Yu, X., Weiler, B., \& Ham, S. (2002). Intercultural communication and mediation: A framework for analysing the intercultural competence of Chinese tour guides. Journal of Vacation Marketing, 8(1), 75-87.

Zeithaml, V. A., Parasuraman, A., \& Berry, L. L. (1990). Delivering quality service: Balancing customer perceptions and expectations. New York, NY: Simon and Schuster.

Zhang, H. Q., \& Chow, I. (2004). Application of importance-performance model in tour guides' performance: Evidence from mainland Chinese outbound visitors in Hong Kong. Tourism Management, 25(1), 81-91.

Zillinger, M., Jonasson, M., \& Adolfsson, P. (2012). Guided tours and tourism. Scandinavian Journal of Hospitality and Tourism, 12(1), 1-7.

\section{Appendix: The Survey Instrument}

\section{Satisfaction With Guided Tour}

SGT01: Compliance with the initial program

SGT02: Early warning of program changes

SGT03: Bus journey time

SGT04: Duration of stay in places visited

SGT05: Frequency of bus stops

SGT06: Bus comfort

SGT07: Professional competence of the bus driver

SGT08: Contacts with local people

SGT09: Tour timetables

SGT10: Interest of places you have visited

\section{Tourist Guide Performance}

TGP01: Knowledge of history

TGP02: Knowledge of geography

TGP03: Knowledge of art and popular culture

TGP04: Mastering entertainment and leisure techniques

TGP05: Mastering leading group techniques and strategies of conflict-solving

TGP06: Knowledge of social etiquette rules and care with personal hygiene

TGP07: Knowledge of first-aid procedures

TGP08: Being a leader, determined, enterprising, practical, dynamic, and active

TGP09: Being empathetic and expressive in communication, reasoning with logic and in a clear way

TGP10: Speaking in an articulated manner and without language vice

TGP11: Being a quiet person, safe and modest, which maintains an emotional balance

TGP12: Being ethical to recommend shopping spots or additional tours 


\section{Destination Image}

DI01: Hospitality

DI02: Tourist information

DI03: Existing infrastructures (airport, accommodation, restaurants, etc.)

DI04: Landscapes

DI05: Beaches

DI06: Gastronomy and wines

DI07: Monuments/museums

DI08: Activities in nature (nautical, sport, well-being, etc.)

DI09: Money for value

DI10: Security 